\title{
PERENCANAAN DERMAGA PELABUHAN PETI KEMAS MALOY DI KUTAI TIMUR
}

\author{
Dian Pranata P. A. \\ Program Studi Teknik Sipil, Universitas Kristen Indonesia Toraja, Jl. Nusantara No.12 Makale 91811, Tana \\ Toraja \\ Email: dian.pranata.putra@gmail.com
}

\begin{abstract}
ABSTRAK
Perencanaan pelabuhan peti kemas Maloy di Kutai Timur adalah untuk menciptakan perkembangan ekonomi yang lebih baik sebagai salah satu kawasan industry serta sistem trnsportasi yang lebih baik pula. Kawasan Maloy membutuhkan sebuah pelabuhan peti kemas yang dapat menghubungkan kawasan ini ke tempat-tempat yang lainnya dengan membawa berbagai hasil sumber daya alam. Untuk membuat sebuah pelabuhan, hal pertama yang perlu dilakukan adalah melakukan sejumlah survey. Survey-survey tersebut diantaranya adalah pemetaan wilayah, pasang surut,analisis angin dan gelombang, serta penyelidikan tanah. Semua survey tersebut harus dilakukan untuk perencanaan yang baik. Kapal yang akan berlabuh di pelabuhan ini adalah kapal peti kemas 40.000 DWT sehingga membutuhkan panjang dermaga $300 \mathrm{~m}$ dan lebarnya $30 \mathrm{~m}$. Dari hasil analisis pasang surut dan gelombang, diperoleh elevasi deck dermaga adalah $5 \mathrm{~m}$ di atas permukaan laut. Jenis dermaga yang digunakan adalah jetty, yang berarti kedalaman air yang dibutuhkan berada jauh dari garis pantai. Dari hasil perhitungan semua pembebanan dengan menggunakan program SAP2000, dermaga ini menggunakan beton bertulang untuk struktru utamanya. Untuk pondasi, dermaga menggunakan tiang pancang tipe "ASTM A252 Spiral Welded Pipe". Ada 4 dimensi tiang pancang yang digunakan yaitu; 700mm, 800mm, 900mm, dan $1000 \mathrm{~mm}$. jenis fender yang digunakan utnuk dermaga adalah fender karet "SCN 1000" yang dapat mempertahankan 34,45 ton energy dan bollard yang digunakan adalah bollard berkapasitas 100 ton.
\end{abstract}

Kata kunci: struktur dermaga, peti kemas

\section{PENDAHULUAN}

Kalimantan Timur merupakan propinsi yang mempunyai sumber daya yang sangat menjanjikan, baik dari sisi tambang atau sumber daya perkebunan. Kawasan Maloy menjadi perhatian pemerintah setempat karena merupakan kawasan khusus yang akan di kembangkan menjadi wilayah industri dan pelabuhan internasional.

Saat ini kawasan maloy telah mempunyai pelabuhan yang terletak di sangkulirang. Pelabuhan ini hanya mampu melayani kapal dengan kapasitas maksimal 5000 DWT.

Keterbatasan ini memberikan kesempatan untuk mengembangkan wilayah maloy dengan pembangunan dermaga yang lebih besar bahkan berskala internasional. Pelabuhan ini adalah pelabuhan CPO yang terletak di Kaliorang, pelabuhan Cargo dan Peti Kemas di Teluk Golok, serta pelabuhan Batubara di Pulau Miang Besar.

Mempertimbangkan hal di atas, Dalam Rencana Induk Pelabuhan Maloy, ditetapkan bahwa terdapat beberapa terminal yang akan dikembangkan di Pelabuhan Maloy, yaitu Terminal Batu Bara, Terminal CPO dan Terminal Kargo (container). Terminal batubara, diproyeksikan akan dikelola oleh Badan Usaha Swasta, dan perencanaan serta pembangunannya murni dana dari investor. Sedangkan Terminal CPO dan Kargo / Kontainer, akan dikelola dengan kerjasama pengelolaan pemerintah dan swasta (Public-Private Partnership). Terminal CPO (Sisi Darat dan Laut) telah memiliki perencanaan (DED dan Amdal), sedangkan terminal kargo/kontainer belum memiliki perencanaan. Oleh karena itulah, dalam tahun Anggaran 2013, dilakukan Perencanaan Terminal Peti Kemas.

\section{METODOLOGI}

Adapun metode penelitian yang akan dilakukan untuk merencanakan dermaga pelabuhan peti kemas maloy sebagai berikut:

a. Survey Topografi dan Bathimetri

- Survey Kondisi Area Lahan Rencana

- Survey Kedalaman Laut (echo sounding) 
b. Analisis Pasang Surut

- Konstanta Pasang Surut

- Tipe Pasang Surut

- Elevasi Muka Air

c. Analisis Gelombang

- Pengolahan Data Angin

- Peramalan Gelombang

d. Survey Penyelidikan Tanah

e. Struktur Dermaga

Topografi dilakukan untuk mendapatkan dan mengetahui kondisi topografi (tinggi rendah daratan, informasi alam, bangunan) yang ada dan lainlainnya. Hasil-hasil survey ini akan digunakan untuk menentukan posisi lokasi bagunan dermaga yang akan dikembangkan, sehingga aman terhadap gangguan baik oleh alam maupun oleh penduduk setempat. Kemudian dipasang Bench Mark sebagai tanda lokasi perencanaan pelabuhan.

Pemeruman atau sounding dilakukan tunuk mengetahui kedalaman dan bentuk dari permukaan laut yang meliputi areal seluas $\pm 40 \mathrm{Ha}$. Pengetahuan mengenai profil bawah laut berguna dalam tinjauan daerah perairan yang menyangkut luas, kedalaman perairan, alur pelayaran, penambatan, tempat labuh dan kemungkinan pengembangan dimasa mendatang.

Tujuan pengamatan gelombang pasang-surut adalah untuk mengetahui elevasi muka air minimum dan maksimum di lokasi studi yang kemudian akan digunakan sebagai dasar perencanaan elevasi bangunan pantai, dalam hal ini pelabuhan. Pengamatan pasang-surut dimulai dengan meletakkan rambu pengamatan (peilshcaal) pada lokasi yang mudah diamati dasar peilschaal harus berada di bawah muka air surut terendah serta dipasang dengan kokoh sehingga berada tidak mudah mengalami perubahan posisi akibat kondisi alam. Puncak peilschaal harus berada di atas batas maksimum pasang yang mungkin terjadi.

Pergerakan angin mengakibatkan gaya pada bangunan, termasuk pelabuhan. Data angin yang digunakan untuk peramalan gelombang merupakan data dipermukaan laut pada lokasi pembangkitan. Tipe data adalah data bulanan maksimum selama 10 tahun.

Pekerjaan penyelidikan tanah dilaksanakan untuk mendapatkan gambaran kondisi litologi profil geoteknis tanah di lokasi pekerjaan pembangunan dermaga dan bangunan pendukung lainnya. Selanjutnya data dan hasil penyelidikan disampaikan sebagai data acuan pada saat perencanaan fondasi suatu bangunan. Pada perhitungan struktur dermaga. Penulis melakukan perencanaan dengan menggunakan aplikasi SAP 2000 V.14.
Langkah pertama yang dilakukan adalah memasukkan model Grid dan memilih jenis satuan yang akan dipakai pada perhitungan. Kemudian setelah itu direncanakan material yang akan digunakan pada struktur serta jenis tulangan. Kemudian ditentukan section properties yang akan digunakan. Setelah itu digambarlah bentang struktur yang akan direncanakan, dalam hal ini adalah struktur dermaga rencana. Setelah itu dimasukkan pula jenis pembebanan yang berlaku dan jenis kombinasi pembebanannya. Apabila sudah dilaksanakan maka dilakukan "Run" pada aplikasi tersebut sehingga ada hasil perhitungan momen negatif maksimum dan momen positif maksimum. Setelah didapatkan momen positif maksimum dan momen negatif maksimum maka dilakukanlah perhitungan untuk tulangan struktur dermaga.

\section{HASIL DAN PEMBAHASAN}

\section{Hasil Pengukuran Topografi dan Bathimetri}

Tabel 1 menunjukkan 2 patok BM yang akan di pasang di lokasi pelabuhan rencana. Setelah patok dipasang, maka dilakukan pengukuran topografi dan titik BM diplot menggunakan GPS.

Tabel 1. Koordinat BM

\begin{tabular}{|c|c|c|c|}
\hline \multirow{2}{*}{$\begin{array}{c}\text { Patok/ } \\
\text { Titik }\end{array}$} & \multicolumn{3}{|c|}{ Koordinat } \\
\cline { 2 - 4 } & $\mathrm{X}$ & $\mathrm{y}$ & $\mathrm{Z}$ \\
\hline BM 01 & 603754,3899 & 89626,3449 & 3,79 \\
\hline BM 02 & 603770,0434 & 89609,0882 & 3,65 \\
\hline
\end{tabular}

Gambar 1 merupakan potongan gambar hasil pengukuran bathimetri di sekitar lokasi perencanaan. Pada hasil pengukuran terlihat bahwa disekitar lokasi perencanaan, kedalaman laut hasil pengukuran di bibir pantai sekitar 2-3 meter. sedangkan untuk kedalaman 13-14 meter, jarak dari bibir pantai berkisar 12,5 kilometer. penentuan letak dermaga akan ditentukan berdasarkan karakteristik kapal yang akan sandar di dermaga.

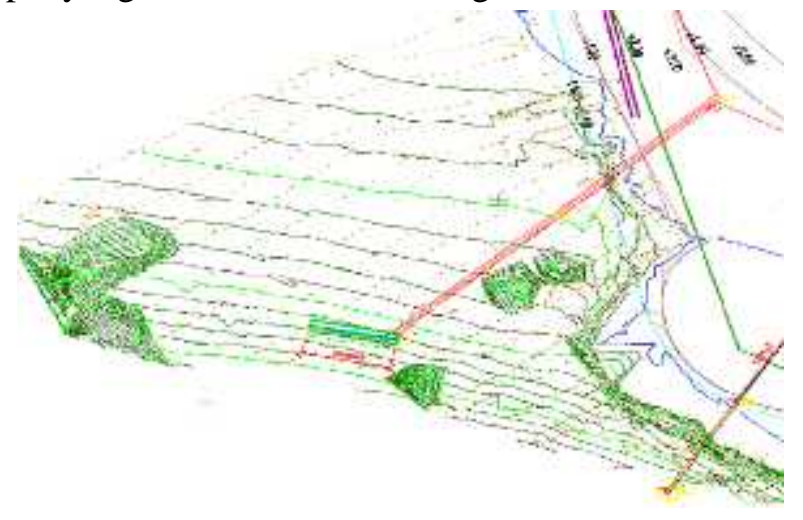

Gambar 1. Hasil Pengukuran Bathimetri 


\section{Analisis Pasang Surut}

Perekaman pasang surut dilakukan untuk mengetahui posisi atau kedudukan muka air di daerah perairan survey, baik untuk kedudukan air tinggi (HWS), muka air rerata (MSL) dan kedudukan air rendah (LWS).

Data mentah pasang surut diolah dengan pemisahan komponen menggunakan metode Admiralty. Pada metode ini terdapat beberapa langkah yang dilakukan dalam bentuk skema. .

Terdapat 7 skema dalam pelaksanaan langkah analisis menggunakan Metode Admiralty. Kemudian dari hasil 7 skema tersebut didapatkan hasil

konstanta peramalan pasang surut yang terdapat

Gambar 2 pada Tabel 2 dan

Tabel 2. Konstanta pasang surut menggunakan metode Admiralty

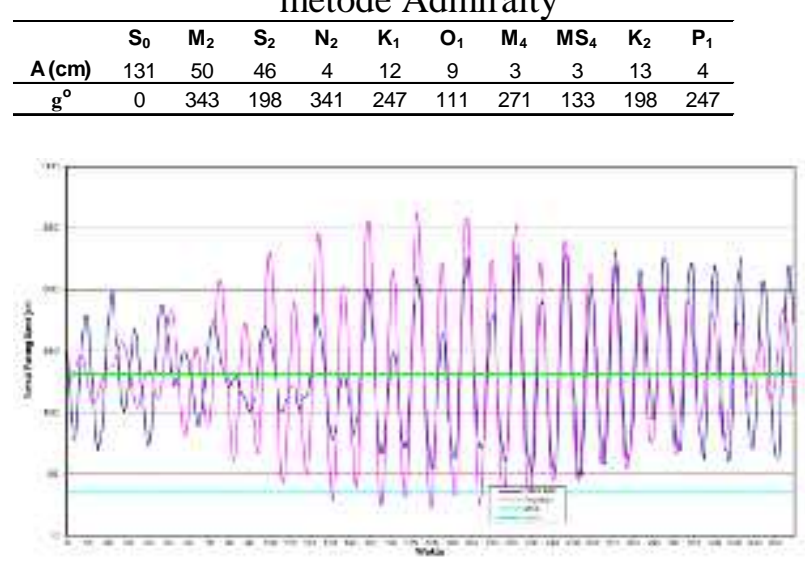

\section{Gambar 2. Grafik Prediksi Pasang Surut Maloy Menggunakan Metode Admiralty}

\section{Peramalan Gelombang}

Dari proses hindcasting didapatkan data gelombang beserta periodanya sebanyak data angin yang dimiliki. Untuk keperluan perhitungan tinggi gelombang rencana, dari data gelombang tersebut dipilih data gelombang maksimum per arah seperti yang disajikan dalam Tabel 3 dan Gambar 3 berikut:

Tabel 3. Tinggi dan Periode Gelombang Pecah Maksimum

\begin{tabular}{|c|c|c|c|c|c|c|}
\hline \multirow[b]{2}{*}{$T_{r}$ (tahun) } & \multicolumn{2}{|c|}{ Tenggara } & \multicolumn{2}{|c|}{ Selatan } & \multicolumn{2}{|c|}{ Barat Daya } \\
\hline & $\mathrm{Hm}_{\mathrm{s}}(\mathrm{m})$ & 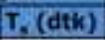 & $\mathrm{Hm}_{\mathrm{B}}(\mathrm{m})$ & $T_{1}(d t k)$ & $\mathrm{Hm}_{\mathrm{s}}(\mathrm{m})$ & $T_{\mathrm{s}}(\mathrm{dtK})$ \\
\hline 200 & 1.20 & 4.86 & 1.84 & 6.01 & 1.71 & 5.80 \\
\hline 100 & 1.19 & 4.84 & 1.69 & 5.76 & 1.54 & 5.50 \\
\hline 50 & 1.19 & 4.84 & 1,58 & 5.57 & 1.38 & 5.21 \\
\hline 25 & 1.19 & 4.84 & 1.51 & 5.45 & 1.22 & 4.90 \\
\hline 10 & 1.18 & 4.82 & 1.45 & 5.34 & 1 & 4.43 \\
\hline 5 & 1.17 & 4.80 & 1.44 & 5,32 & 0.82 & 4.02 \\
\hline 3 & 1.15 & 4.75 & 1,44 & 5.32 & 0.69 & 3.68 \\
\hline 2 & 1.14 & 4.73 & 1.43 & 5,30 & 0.56 & 3.32 \\
\hline 1 & 1.03 & 4.50 & 0.88 & 4.16 & 0.21 & 2.03 \\
\hline
\end{tabular}

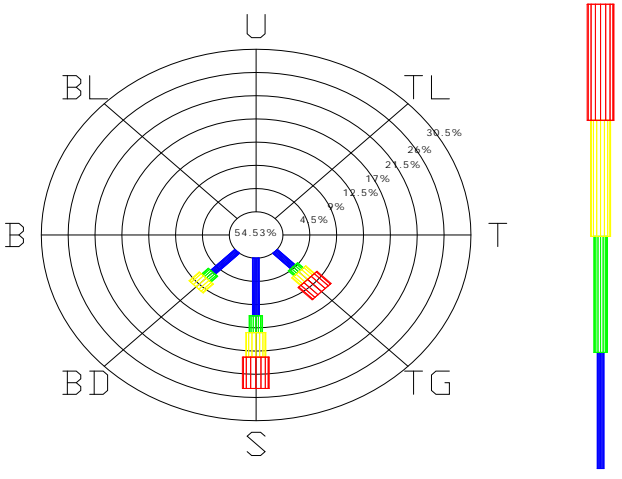

Gambar 3. Waverose Berdasarkan Hasil Peramalan Gelombang

\section{Karakteristik Kapal Desain}

Dermaga Pelabuhan Peti Kemas Maloy direncanakan akan melayani kapal peti kemas 40.000 DWT(Gambar 4). Berikut adalah data kapal yang akan digunakan pada proses desain dermaga Pelabuhan Peti Kemas Maloy.

$\begin{array}{ll}\text { Tipe kapal } & : \text { Kapal Peti Kemas } \\ \text { Tonase } & : 40.000 \text { DWT } \\ \text { Panjang (Loa) } & : 263 \mathrm{~m} \\ \text { Lebar } & : 33,5 \mathrm{~m} \\ \text { Draft penuh } & : 12,4 \mathrm{~m}\end{array}$

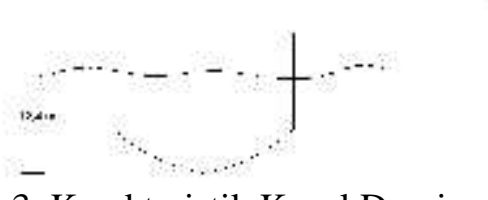

Gambar 3. Karakteristik Kapal Desain

\section{Tipe Dermaga}

Tipe dermaga yang dipilih yaitu berbentuk jetty. Dermaga ini dibangun bila garis kedalaman jauh dari pantai dan perencana tidak menginginkan adanya pergerukan kolam pelabuhan yang besar. Antara dermaga dan pantai dihubungkan dengan jembatan penghubung (approach trestle) sebagai penerus dari pergerakan barang. Jembatan penghubung dapat ditempatkan di tengah, di sisi atau kombinasi.

Untuk jenis struktur yang digunakan adalah Deck On Pile. Struktur Deck On Pile menggunakan tiang pancang sebagai pondasi bagi lantai dermaga. Seluruh beban di lantai dermaga diterima sistem lantai dermaga dan tiang pancang tersebut. 


\section{Elevasi Dermaga}

Untuk menentukan elevasi bangunan, terlebih dahulu ditentukan elevasi muka air laut rencana yang akan ditambahkan dengan tinggi jagaan.

Elevasi muka air laut rencana merupakan penjumlahan dari beberapa parameter yaitu: pasang surut (MHWL), wave setup ( $\mathrm{Sw}$ ) dan pemanasan global (SLR).

Berdasarkan pengamatan pasang surut diperoleh ; $\mathrm{HAT}=2,354 \mathrm{~m}$, dari elevasi $0,00(\mathrm{LAT}) ; \mathrm{Hb}=1,84$ $\mathrm{m}$ (diambil dari gelombang rencana pada periode 200 tahun); periode gelombang, $\mathrm{T}=6,01 \mathrm{detik}$

Maka Sw $=0,209 \mathrm{~m}$

Berdasarkan grafik pada buku Teknik Pantai, Bambang Triatmojo, 1999 hal. 115, diperoleh tinggi muka air akibat pemanasan global $(\mathrm{SLR})=0,2 \mathrm{~m}$

Jadi elevasi tinggi bangunan dengan memperhitungkan tinggi kebebasan adalah 2,00 m, adalah $4,763 \mathrm{~m} \approx 5,00 \mathrm{~m}$ dari elevasi LAT

\section{Panjang Dermaga}

Panjang dermaga untuk satu tambatan, yaitu sama dengan panjang kapal terbesar yang menggunakan dermaga ditambah masing-masing $10 \%$ panjang kapal di ujung hulu dan buritan kapal.

$$
\begin{aligned}
\mathrm{Lp} & =\mathrm{Loa}+20 \% \mathrm{Loa} \\
& =263+0,2(263)=300 \mathrm{~m}
\end{aligned}
$$

\section{Analisis Pembebanan Dermaga}

Untuk merencanakan struktur dermaga, terlebih dahulu harus dilakukan analisis pembebanan dermaga. Untuk analisis ini, digunakan program SAP2000 v.14. hasil yang ingin didapatkan pada analisis pembebanan dermaga ialah momen positif maksimum dan momen negatif maksimum. Adapun pembebanan yang dianalisis pada struktur dermaga sebagai berikut:

1. Beban Mati

2. Beban Hidup

3. Beban Berjalan

4. Beban Angin

5. Beban Gelombang

6. Beban Gempa

7. Beban Berthing

8. Beban Mooring

Setelah itu dilakukan kombinasi pembebanan yaitu sebagai berikut:
a. 1,2 DL +1,6 LL
b. $1,2 \mathrm{DL}+1,6 \mathrm{Hs}$
c. $1,2 \mathrm{DL}+30 \% \mathrm{LL}+\mathrm{Hs}$
d. $0,75(1,2 \mathrm{DL}+1,6 \mathrm{LL}+1,6 \mathrm{Hb}) \backslash$
e. $0,9 \mathrm{DL}+1,3 \mathrm{Hb}$
f. $0,75(1,2 \mathrm{DL}+1,6 \mathrm{LL}+1,6(\mathrm{Hw}+\mathrm{Hc}) \max )$
g. $0,9 \mathrm{DL}+1,3(\mathrm{Hw}+\mathrm{Hc}) \max$

h. $1,05(\mathrm{DL}+50 \% \mathrm{LL}+\mathrm{Hg})$

$$
\begin{array}{ll}
\mathrm{DL} & =\text { beban mati } \\
\mathrm{LL} & =\text { beban hidup } \\
\mathrm{Hs} & =\text { beban tambat } \\
\mathrm{Hb} & =\text { beban tarik } \\
\mathrm{Hw} & =\text { beban angin } \\
\mathrm{Hc} & =\text { beban arus } \\
\mathrm{Hg} & =\text { beban gempa }
\end{array}
$$

\section{Perencanaan Balok Dermaga}

Terdapat 3 tipe balok dermaga yang direncanakan yang kemudian disimulasikan pada program SAP2000 v.14 untuk memperoleh Mpos dan Mneg maksimal untuk tiap tipe balok. Setelah diperoleh momen-momen maksimal untuk tiap balok, kemudian dilakukan perhitungan untuk penulangan balok dengan mutu beton f'c=33,2 MPa dan mutu baja $\mathrm{fy}=320 \mathrm{MPa}$

1. Balok Ukuran $80 \times 60 \mathrm{~cm}$

- Mpos : 14,978 ton.m

- Mneg : -15,236 ton.m

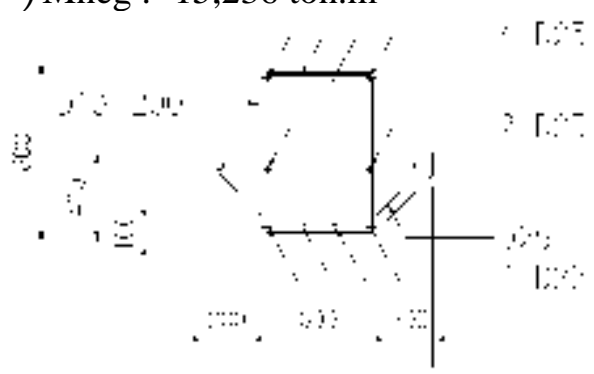

Gambar 4. Detail penulangan balok ukuran 80x60 $\mathrm{cm}$

2. Balok Ukuran $100 \times 80 \mathrm{~cm}$

- Mpos : 21,095 ton.m

- Mneg : -20,216 ton.m

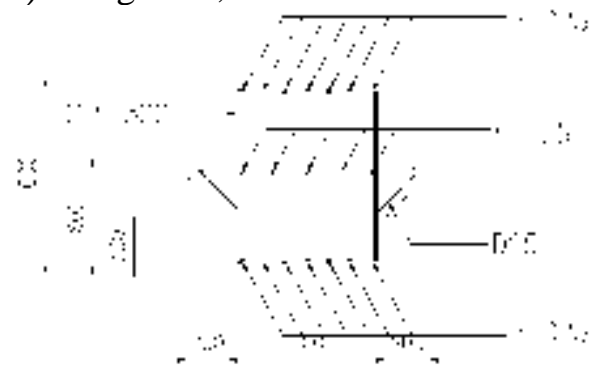

Gambar 5. Detai penulangan balok ukuran 100x80 $\mathrm{cm}$

3. Balok Ukuran $160 \times 120 \mathrm{~cm}$

- Mpos : 33,985 ton.m

- Mneg : -35,561 ton.m 


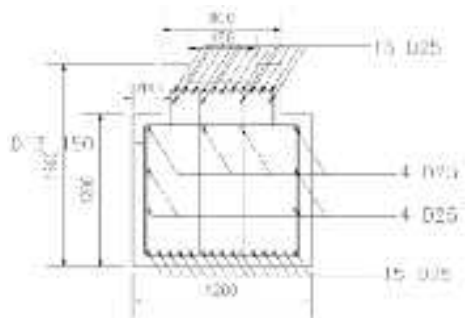

Gambar 6. Detail penulangan balok ukuran 160x120 $\mathrm{cm}$

Dari perhitungan struktur untuk balok melintang dan balok memanjang dermaga maka didapatkan penulangan dermaga yang ditampilkan pada Tabel 4 berikut:

Tabel 4. Tabel Rekapitulasi Penulangan pada Balok Dermaga

\begin{tabular}{|l|l|l|l|}
\hline \multicolumn{1}{|c|}{ Tipe Balok } & \multicolumn{2}{|c|}{ Tul. Utama } & \multicolumn{1}{c|}{ Tul. Geser } \\
\hline $\begin{array}{l}\text { Balok } \\
\text { Memanjang } \\
\text { 80x60cm }\end{array}$ & 4 D 25 & M (-) & D13-200 \\
\hline $\begin{array}{l}\text { Balok } \\
\text { Melintang } \\
\text { 100x80cm }\end{array}$ & 7 D 25 & M (-) & \\
\hline $\begin{array}{l}\text { Balok Crane } \\
\text { 160x120cm }\end{array}$ & 17 D 25 & M (+) & D13-300 \\
\hline
\end{tabular}

\section{Perencanaan Lantai Dermaga}

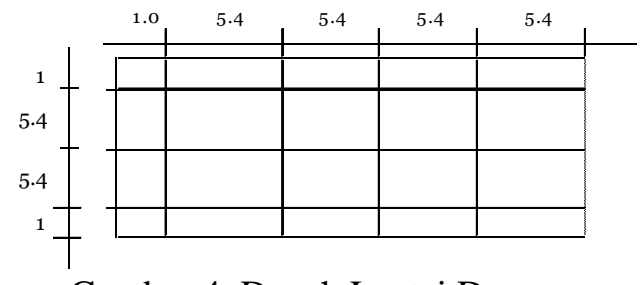

Gambar 4. Denah Lantai Dermaga

Lantai dermaga terbuat dari konstruksi beton bertulang dengan:

$$
\begin{array}{ll}
\text { - Tebal pelat } & =40 \mathrm{~cm} \\
\text { - Mutu beton } & =33,2 \mathrm{Mpa} \\
\text { - Mutu baja (fy) } & =320 \mathrm{Mpa}
\end{array}
$$

Tabel 5. Perhitungan pembebanan 1,2 DL + 1,6 LL pada lantai dermaga

\begin{tabular}{|c|c|c|c|c|}
\hline Momen & $\begin{array}{c}\text { Berat } \\
\text { Sendiri }\end{array}$ & $\begin{array}{c}\text { Beban } \\
\text { Merata }\end{array}$ & Truck & $\begin{array}{c}\text { Beban } \\
\text { Rencana }\end{array}$ \\
\hline \hline MLx & 0,6185 & 1,2247 & 2,3647 & 5,7968 \\
\hline MLy & 0,6185 & 1,2247 & 2,6755 & 6,2941 \\
\hline Mtx & $-1,5315$ & $-3,0326$ & $-4,1437$ & $-11,6151$ \\
\hline Mty & $-1,5315$ & $-3,0326$ & $-3,8663$ & $-11,1712$ \\
\hline
\end{tabular}

Dari perhitungan struktur untuk lantai dermaga (Gambar 4) maka didapatkan rekapitulasi tulangan untuk lantai dermaga sebagai berikut:

Tabel 4. Rekapitulasi penulangan Lantai Dermaga

\begin{tabular}{|l|c|c|}
\hline Penulangan Lantai & Tulangan & Ket. \\
\hline Tumpuan & D19-150 & $\mathrm{M}(-)$ \\
\hline Lapangan & $\mathrm{D} 19-150$ & $\mathrm{M}(+)$ \\
\hline
\end{tabular}

\section{Perhitungan Poer Dermaga}

Penulangan poer dermaga dianalisa berdasarkan gaya-gaya maksimum yang bekerja pada balok tertumpu pada poer tunggal. Ada tiga tipe poer yang digunakan pada dermaga yaitu:

1. Ukuran $140 \times 140 \times 140 \mathrm{~cm}$

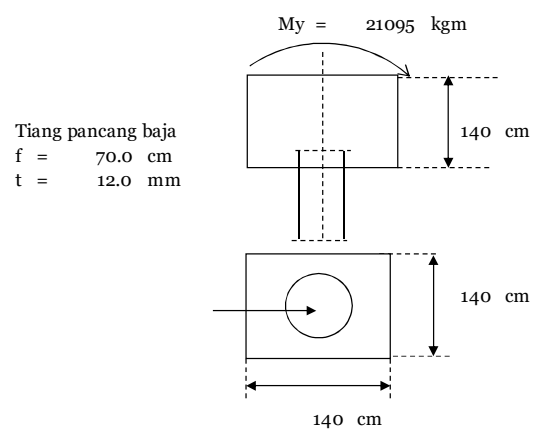

2. Ukuran $200 \times 200 \times 160 \mathrm{~cm}$

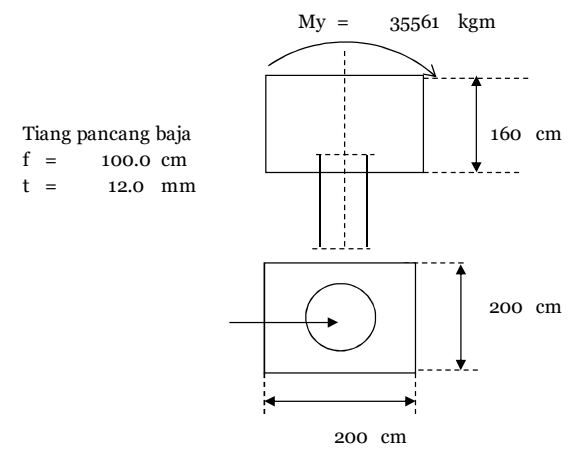

3. Ukuran $200 \times 340 \times 140 \mathrm{~cm}$

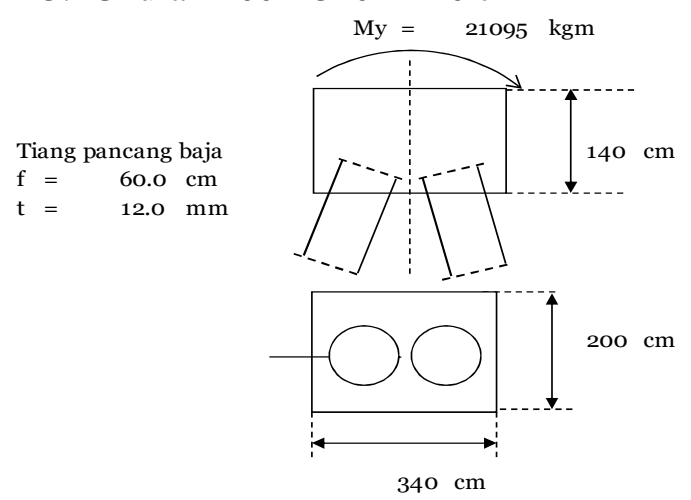

Berdasarkan perhitungan struktur untuk poer dermaga, didapatkan tulangan yang ditampilkan pada berikut: 
Tabel 5. Penulangan Poer Dermaga

\begin{tabular}{|l|l|l|}
\hline Poer Dermaga & \multicolumn{1}{|c|}{ Tul. Utama } & \multicolumn{1}{|c|}{ Tul. Geser } \\
\hline 140x140x140cm & 17 D25 & D13-200 \\
\hline 200x200x160cm & 27 D 25 & D13-150 \\
\hline 200x340x140cm & 24 D 25 & D13-100 \\
\hline
\end{tabular}

\section{Perencanaan Pondasi Tiang Pancang}

Analisis mekanika teknik menggunakan program berbasis elemen hingga dengan tinggi struktur diambil dari titik jepit (point of fix) ke elevasi tertinggi dari struktur (pelat lantai).

Perhitungan letak titik jepit tanah terhadap tiang pancang untuk tanah normally consolidated clay dan granular soil, digunakan persamaan:

$\mathrm{Zf}=1.8 \mathrm{~T}$

Dengan $T=\sqrt[5]{\frac{E}{n h}}$

$\mathrm{E} \quad=$ modulus elastisitas tiang pancang

I = inersia tiang pancang

$\mathrm{Nh}=350-700 \mathrm{kN} / \mathrm{m}^{3}$, untuk soft normally consolidated clays

Diambil nh $\quad=350 \mathrm{kN} / \mathrm{m}^{3}=0.035 \mathrm{~kg} / \mathrm{cm}^{3}$

Jadi letak titik jepit terhadap tanah berdasarkan nilai SPT untuk:

- Tiang pancang baja $\emptyset 1000 \mathrm{~mm}$, maka nilai $\mathrm{Z}_{\mathrm{f}}=4,38 \mathrm{~m}$

- Tiang pancang baja $\emptyset 900 \mathrm{~mm}$, maka nilai $\mathrm{Z}_{\mathrm{f}}=4,15 \mathrm{~m}$

- Tiang pancang baja $\varnothing 800 \mathrm{~mm}$, maka nilai $\mathrm{Z}_{\mathrm{f}}=3,91 \mathrm{~m}$

- Tiang pancang baja $\varnothing 700 \mathrm{~mm}$, maka nilai $\mathrm{Z}_{\mathrm{f}}=3,65 \mathrm{~m}$

Tabel 8. Rekapitulasi Gaya Aksial Maksimum, Gaya Geser Minimum, dan Momen Maksimum Pada Tiang

\begin{tabular}{|c|c|c|c|c|c|}
\hline \multirow[b]{2}{*}{ No } & \multirow[b]{2}{*}{ struktur I'onibasl I lang. } & \multicolumn{2}{|c|}{ Gilya Alusind } & \multirow{2}{*}{$\begin{array}{l}\text { Givya Gewer } \\
\text { Inn }\end{array}$} & \multirow{2}{*}{$\begin{array}{l}\text { Mlosuen } \\
\mathrm{im}\end{array}$} \\
\hline & & $\begin{array}{c}\text { Twing } \\
\text { uil }\end{array}$ & $\begin{array}{c}\text { Turde } \\
\text { üII }\end{array}$ & & \\
\hline 1 & nilio & $29+.2$ & $-105,1.5$ & 1.42 & 34,55 \\
\hline$?$ & $127 \%$ & $13 x: i=$ & $4 \times 14$ & 1.21 & $15: 75$ \\
\hline 3 & Th8 & 137.0 & -89.30 & 0,25 & $7.3 \bar{y}$ \\
\hline 4 & 1240 & $|i s 4 . .31|$ & $-\$ 0.2 y$ & $1, y 3$ & pios \\
\hline
\end{tabular}

Tabel 9. Tabel Kontrol Tiang Pancang terhadap Defleksi

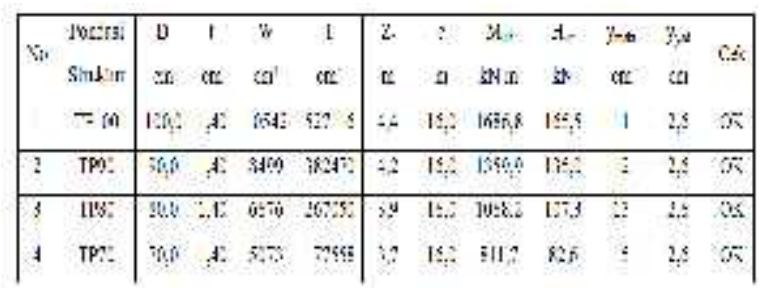

Tabel 10. Kontrol Terhadap Tekuk, Momen

Tahanan Tiang, Gaya Horizontal Ultimate, dan Kekuatan Bahan

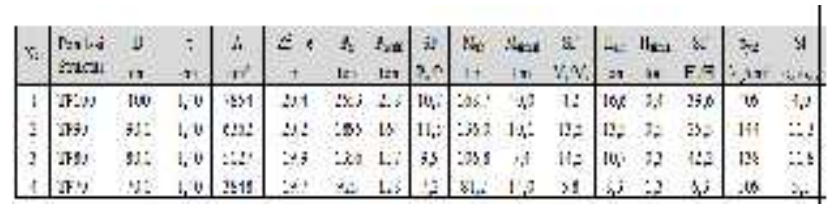

Berdasarkan hasil perhitungan di atas disimpulkan bahwa material tiang pancang baja mampu menahan beban-beban yang bekerja

\section{Perencanaan Fender}

Fender direncanakan menahan kapal peti kemas besar yang berukuran 40.000 DWT. Dalam perencanaan fender dianggap bahwa kapal dengan muatan penuh merapat ke dermaga dengan membentuk sudut $10^{\circ}$ terhadap sisi depan dermaga.

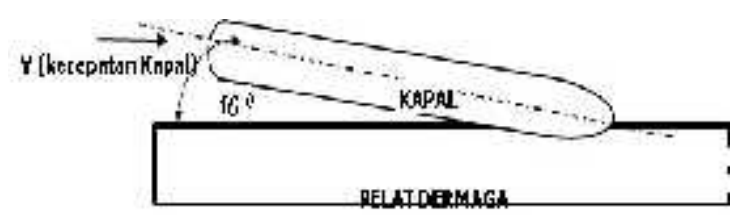

Gambar 8. Sudut Benturan Kapal Terhadap Dermaga

Dari keseluruhan data tersebut didapat besar energi benturan sebagai berikut:

$$
\begin{aligned}
\mathrm{E} & =\frac{\mathrm{WV}^{2}}{2 \mathrm{~g}} \cdot \mathrm{Ce} \cdot \mathrm{Cm} \cdot \mathrm{Cs} \cdot \mathrm{Cc} \\
& =49331 \frac{0,15^{2}}{2 \cdot 9,81} \cdot 0,4 \cdot 1,27 \cdot 1,0 \cdot 1,0 \\
& =28,126 \text { ton.m }
\end{aligned}
$$

Maka energi yang diterima oleh dermaga yaitu 28,126 ton.m dari energi benturan tersebut digunakan fender karet "SCN 1000" dengan data sebagai berikut:

$$
\begin{aligned}
& \text { Kapasitas }=66,56 \text { ton } \\
& \text { Energi }=34,35 \text { ton.m } \\
& \text { Luas Kontak } 0.32 \mathrm{~m}^{2}
\end{aligned}
$$

Jarak maksimum antar fender:

$$
\begin{aligned}
L & =2 \sqrt{r^{2}-(r-h)^{2}} \\
& =2 \sqrt{16,75^{2}-(16,75-1,5)^{2}} \\
& =13,85 m
\end{aligned}
$$

Diambil jarak antar fender 10,8 m tepat pada jalur balok melintang dengan jumlah fender sebanyak 6 buah

\section{Perencanaan Balok Fender}

Ukuran balok fender yaitu $60 \times 100 \mathrm{~cm}$ dengan panjang bidang kontak 2,0 $\mathrm{m}$ dan gaya reaksi 67,5 ton. Maka momen yang terjadi pada fender sebesar $238038,137 \mathrm{~kg} . \mathrm{m}$ 
Dari momen yang terjadi pada fender, dilakukan perhitungan tulangan dan didapatkan rekapitulasi perhitungan tulangan sebagai berikut

Tabel 11. Rekapitulasi Penulangan Balok Fender

\begin{tabular}{|c|c|c|}
\hline Tipe Balok & Tul. Utama & Tul. Geser \\
\hline $\begin{array}{c}\text { Balok Fender } \\
60 x 100 \mathrm{~cm}\end{array}$ & $21 \mathrm{D} 25$ & D25-250 \\
\hline
\end{tabular}

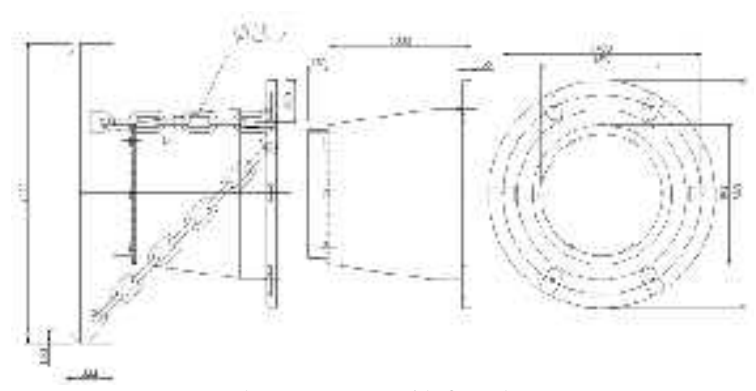

Gambar 9. Detail fender rencana

\section{Perencanaan Bollard}

Dalam merencanakan bollard disyaratkan agar tinggi bitt tidak melebihi $50 \mathrm{~cm}$ di atas lantai dermaga. Hal ini dilakukan agar tidak mengganggu kelancaran arus naik turun peti kemas di dermga.

Gaya tarik yang bekerja pada bitt diperhitungkan sebesar 100 ton. Bahan bollard digunakan baja dengan kuat izin yang sama, yaitu fy= $320 \mathrm{MPa}$. Jarak dan jumlah bitt minimum untuk beberapa ukuran kapal yang diisyaratkan dapat dilihat pada tabel.

Tabel 12. Penempatan bollard

\begin{tabular}{|c|c|c|}
\hline $\begin{array}{c}\text { Ukuran Kapal } \\
(\text { GRT })\end{array}$ & $\begin{array}{c}\text { Jarak } \\
\text { Maksimum } \\
(\mathrm{m})\end{array}$ & $\begin{array}{c}\text { Jumlah } \\
\text { Minimal } \\
\text { Tambatan }\end{array}$ \\
\hline$<2.000$ & $10-15$ & 4 \\
$2.001-5.000$ & 20 & 6 \\
$5.001-20.000$ & 25 & 6 \\
$20.001-50.000$ & 35 & 8 \\
$50.001-100.000$ & 45 & 8 \\
\hline
\end{tabular}

Bollard direncanakan sebanyak 12 buah dengan jarak antar bollard $25 \mathrm{~m}$.

\section{KESIMPULAN DAN SARAN}

\section{Kesimpulan}

1. Dari hasil análisis pasang surut ditentukan elevasi struktur dermaga yaitu $+5,00 \mathrm{~m}$ dari LAT.

2. Tipe dermaga yang direncanakan adalah Deck on Pile dengan dimensi dermaga $300 \mathrm{~m} \times 30 \mathrm{~m}$ yang terbagi atas 6 bagian $50 \mathrm{~m}$ x $30 \mathrm{~m}$.
3. Untuk penulangan balok, terdapat 3 tipe balok yang digunakan yaitu:

a. Balok $60 \times 80 \mathrm{~cm}$, dengan tulangan utama 4 D 25 dan tulangan geser D13-200 mm.

b. Balok $80 \times 100 \mathrm{~cm}$, dengan tulangan utama 7 D 25 dan tulangan geser D13-300 mm.

c. Balok $120 \times 160 \mathrm{~cm}$, dengan tulanga utama 17 D 25 dan tulangan geser D13-150 mm.

4. Tiang pancang yang digunakan jenis pipa baja stándar ASTM A252 Spiral Welded Pipe. Pada struktur dermaga digunakan 4 jenis tiangpancang dengan rincian sebagai berikut:
a. Tiang Pancang Diameter $1000 \mathrm{~mm}$
b. Tiang Pancang Diameter $900 \mathrm{~mm}$
c. Tiang Pancang Diameter $800 \mathrm{~mm}$
d. Tiang Pancang Diameter $700 \mathrm{~mm}$

5. Fender yang digunakan adalah fender karet SCN 1000 dengan spesifikasi sebagai berikut:

$$
\begin{array}{ll}
\text { Kapasitas, R } & =66,56 \text { ton } \\
\text { Energi, E } & =34,45 \text { ton } . \mathrm{m}
\end{array}
$$

Direncanakan jarak antar fender 10,8 m tepat pada jalur balok melintang dengan jumlah fender sebanyak 6 buah

6. Direncanakan bollard dengan kapasitas 100 ton. Bollard direncanakan sebanyak 12 buah dengan jarak antar bollard $25 \mathrm{~m}$.

\section{Saran}

1. Permodelan sedimentasi tidak dilakukan, dalam perencanaan pelabuhan yang menyeluruh permodelan sedimentasi ini sangat dibutuhkan.

2. Sebaiknya dilakukan perhitungan tentang tingkat keekonomisan perencanaan dengan membandingkan beberapa laternatif perhitungan. 


\section{DAFTAR PUSTAKA}

Anandika, Arya. 2005. Kajian Kedalaman Minimum Tiang Pancang Pada Struktur Dermaga Deck on Pile. Institut Teknologi Bandung

Nawy, Edward G. 1990. Beton Bertulang Suatu Pendekatan Dasar. Bandung: PT. Eresco.

Kramadibrata, Soedjono. 2002. Perencanaan Pelabuhan. Bandung : Penerbit ITB.

Pramanto, Renny. 2011. Perencanaan Struktur Gedung Pusat Niaga Malili Kabupaten Luwu Timur. Universitas Hasanuddin

RSNI T-02-2005. Standar Pembebanan Untuk Jembatan. Jakarta: Badan Standarisasi Nasional

SNI T-15-1991-2003. Tata Cara Perhitungan Struktur Beton untuk Bangunan Gedung. Jakarta : Badan Standardisasi Nasional.

SNI 03-1726-2012. Tata Cara Perencanaan Ketahanan Gempa Untuk Bangunan Gedung. Jakarta : Badan Standardisasi Nasional.

SNI 03-2847-2002. Tata Cara Perhitungan Struktur Beton Untuk Bangunan Gedung. Jakarta : Badan Standardisasi Nasional.

Standards For Port And Harbour Facilities in Japan. Tokyo, Japan. 2002.

Triatmodjo, Bambang. 1999. Teknik Pantai. Yogyakarta : Beta Offset .

Triatmodjo, Bambang. 2010. Perencanaan Pelabuhan. Yogyakarta : Beta Offset. 